\title{
Article
}

\section{Heat Capacity of Drained Peat Soils}

\author{
Tomasz Gnatowski ${ }^{1, *(1)}$, Ewa Ostrowska-Ligęza ${ }^{2}\left(\mathbb{D}\right.$, Cedric Kechavarzi $^{3}$, Grzegorz Kurzawski ${ }^{1}$ \\ and Jan Szatyłowicz ${ }^{1}$ (i)
}

1 Department of Environmental Management, Institute of Environmental Engineering, Warsaw University of Life Sciences-SGGW, 02-776 Warsaw, Poland; grzegorz_kurzawski@sggw.edu.pl (G.K.); jan_szatylowicz@sggw.edu.pl (J.S.)

2 Department of Chemistry, Institute of Food Sciences, Warsaw University of Life Sciences-SGGW, 02-776 Warsaw, Poland; ewa_ostrowska_ligeza@sggw.edu.pl

3 Department of Engineering, University of Cambridge, Cambridge CB2 1PZ, UK; ck209@cam.ac.uk

* Correspondence: tomasz_gnatowski@sggw.edu.pl

check for updates

Citation: Gnatowski, T.; OstrowskaLigęza, E.; Kechavarzi, C.; Kurzawski, G.; Szatyłowicz, J. Heat Capacity of Drained Peat Soils. Appl. Sci. 2022, 12, 1579. https://doi.org/10.3390/app 12031579

Academic Editor:

Maria Mavroulidou

Received: 8 December 2021

Accepted: 29 January 2022

Published: 1 February 2022

Publisher's Note: MDPI stays neutral with regard to jurisdictional claims in published maps and institutional affiliations.

Copyright: () 2022 by the authors Licensee MDPI, Basel, Switzerland. This article is an open access article distributed under the terms and conditions of the Creative Commons Attribution (CC BY) license (https:// creativecommons.org/licenses/by/ $4.0 /)$.
Featured Application: The results of the study can be applied for the peat soil parametrization for heat movement modeling purposes.

\begin{abstract}
Soil-specific heat capacity $\left(c_{p}\right)$ and volumetric heat capacity $\left(C_{v}\right)$ are recognized as a fundamental soil property essential for the accurate prediction of soil temperature and heat flow. This study presents the analysis of these thermal properties for drained peat soils in Poland. The objectives of this study were to (i) measure and develop a method for determining $c_{p}$, (ii) analyze the $\left(C_{v}\right)$ data for undisturbed soil samples from surface layers, and (iii) test the applicability of the $c_{p}$ value for calculating $C_{v}$ of drained peat soils using the mixing model concept. The $c_{p}$ value was measured under laboratory conditions using a modulated differential scanning calorimetry (MDSC) for 18 soil layers sampled in six degraded peat soil profiles. The $C_{v}$ was estimated for undisturbed triplicate soil samples from the 22 depths (66 samples) by using a dual-needle probe. The $c_{p}$ data for the organic soils were linearly temperature-dependent (MDSC) for the temperature range considered $\left(-20-30{ }^{\circ} \mathrm{C}\right)$. The overall average $c_{p}$ value was equal to $1.202 \mathrm{~J} \mathrm{~g}^{-1} \mathrm{~K}^{-1}$ at a temperature of $0{ }^{\circ} \mathrm{C}$. An increment in temperature of $1{ }^{\circ} \mathrm{C}$ corresponded to an increase in $c_{p}$ of $0.0043 \mathrm{~J} \mathrm{~g}^{-1} \mathrm{~K}^{-1}$ on average. Nevertheless, the lowest $c_{p}$ value was obtained for moss samples whereas the highest value represents alder peats. The $C_{v}$ data measured using the heat thermal probe (HTP) method changed linearly with changes in the soil moisture content $\left(\theta_{v}\right)$ of the moorsh soils. The volumetric heat capacity calculated using the mixing model was comparable to the mean of measured values obtained on the triplicate samples.
\end{abstract}

Keywords: heat capacity; peat-muck; mixing model; soil properties; regression

\section{Introduction}

Peat soils represent unique physical properties [1] which mainly depend on the type of the organic materials [2] and advancement of decay processes in the soil surface layers [3]. The low value of the soil bulk density reflects in the high organic matter content (low amount of ash content) of the peat soils. The soil bulk density and ash content are often used as descriptive variables for predicting more detailed peat physical parameters like soil moisture retention and hydraulic properties [4]. The organic carbon and nitrogen contents vary in peat soils and depend on the different soil management and land use [5]. Both features representing the C:N ratio indicate the degradation of the organic matter [6] influencing nitrous oxide emissions [7] accompanied by the groundwater level position fluctuation [5]. The agricultural use of peatlands results in lowering the groundwater level, increasing soil surface layers oxidation, and transforming peatlands into the source of the $\mathrm{CO}_{2}$ efflux to the atmosphere. Soil $\mathrm{CO}_{2}$ efflux combines the effect of heterotrophic (bacterial) 
and autotrophic (root) respiration. Although these two sources are difficult to separate, they often are additive and treated as a total soil respiration [8]. The measured amount of the $\mathrm{CO}_{2}$ efflux in peat soils depends on soil temperature, groundwater level position [9], and soil moisture content [10]. The empirical investigation proved that greenhouse gases modeling, besides other environmental factors, depends on the soil temperature dynamics [11]. The volumetric heat capacity $\left(C_{v}\right)$ is a complex soil property which is used in the studies of soil temperature and heat flow. It includes knowledge about soil thermal status but also incorporates information about soil physical properties (soil bulk density and volumetric moisture content). Thus, $C_{v}$ is often expressed in the form of a mixing model as the sum of volume fractions of thermal capacities of the individual soil components, i.e., solid, liquid, and gaseous [12]. In practical applications the $C_{v}$ value can be estimated by neglecting the gaseous phase and by considering only two soil constituents, i.e., solid and water phases [13]. Because the specific heat capacity and density of water $\left(c_{w}\right.$ and $\rho_{w}$, respectively) are commonly known, to determine $C_{v}$ using a mixing model the specific heat capacities $\left(c_{p}\right)$ for solid particles should be measured independently. The $c_{p}$ values for soil mineral constituents are in the range of approximately 0.718 to $0.939 \mathrm{~J} \mathrm{~g}^{-1} \mathrm{~K}^{-1}$ [13-15]. The published data of de Vries (1963) [12] show that for organic soils the $c_{p}$ values range from 1.738 to $1.994 \mathrm{~J} \mathrm{~g}^{-1} \mathrm{~K}^{-1}$ with a value of $1.925 \mathrm{~J} \mathrm{~g}^{-1} \mathrm{~K}^{-1}$ at an average particle density $1.300 \mathrm{~g} \mathrm{~cm}^{-3}$. In studies on investigation of the heat transfer in the boreal bog, the $c_{p}$ values for organic soils were between 1.380 and $2.000 \mathrm{~J} \mathrm{~g}^{-1} \mathrm{~K}^{-1}$ [16].

For the past four decades the most widely used technique for studying specific heat capacity as a function of temperature has been the modulated differential scanning calorimetry (MDSC) method. This method has been developed by combining the conventional differential scanning calorimetry (DSC) and the temperature modulated calorimetry (TMC) techniques. The improvements in the MDSC technique involve the application of a sinusoidal heating or cooling signal to a sample and the subsequent measurement of the reversing and non-reversing components of the heat flow response [17,18]. Kozlowski (2012) [19], using this method, indicated that the heat capacity of the homoionic forms of bentonite and kaolinite is linearly dependent on temperature in the range of -70 to $30^{\circ} \mathrm{C}$. DeLapp and LeBoeuf (2004) [20], using the MDSC method, stated that the $c_{p}$ value for selected peat and soil sediments is different for temperatures of $0{ }^{\circ} \mathrm{C}$ and $25^{\circ} \mathrm{C}$.

The $C_{v}$ value can also be quantified experimentally by using the heat thermal probe method (HTP). This technique is based on the solution of the radial heat conduction equation for a line heat source in a homogeneous and isotropic medium with a uniform initial temperature [21-23]. One factor of the attractiveness of the mixing model is that if $c_{p}$ is known, and if $C_{v}$ has been determined experimentally, it can be used to estimate soil moisture content [24-27] and soil dry bulk density [27]. Ren et al. (2003) [25] indicate that this approach can provide accurate estimates of the moisture content in mineral soils. Lu et al. (2013) [15] suggest that the heat pulse method can also be used satisfactorily to estimate the soil specific heat capacity of mineral soil using the quotient of the $C_{v}$ value and soil bulk density. For a better estimation of specific heat, the authors propose the use of temperature distribution data obtained at later times, when the temperature generated by the heat pulse probe starts to decay. This assumption enables reducing the estimation error of the $c_{p}$ comparing to DSC data. The main limitations of the heat pulse method are regarding the geometry of the heater and response element, which records the temperature. Both require calibration to account for these effects and to improve the accuracy of volumetric heat capacity measurements and consequently the estimation of other soil properties such as soil water content and soil bulk density $[23,28,29]$. Regardless of the limitations of the heat pulse method, it is currently one of the most informative techniques that can be used for the study of soil thermal status and soil water-related processes [30,31]. Applying this method to organic peat materials is attractive because of their tendency to change geometry during the drying process [32-34], which occurs during the vegetation season under natural condition and leads to changes in soil bulk density [35]. The "direct" measurements of $C_{v}$ using HTP probe can eliminate the need 
to determine the soil bulk density which is needed in the mixing model. There is limited information in the literature about the applicability of the MDSC and HTP methods in peat soil. The calorimetrical method is rather implemented in organic soil to study glass transition temperature $[20,36]$. The data regarding the influence of temperature on specific heat capacity are only described in the work of DeLapp and LeBoeuf (2004) [20]. In the case of the heat pulse method, there are only limited studies where it is applied to peat soils [37-40].

The motivation of this study was to measure the specific heat capacity as a function of the temperature $\left(c_{p}(T)\right)$ of different peat materials commonly occurring in drained peatland deposits using the MDSC method. We hypothesized that peat soil materials with differential chemical and physical properties characterize contrasted $c_{p}(T)$ characteristics. Hence, we tried to develop an approximation method of the specific heat using basic soil properties. The proper $c_{p}$ value is crucial for calculating the volumetric heat capacity of peat soils variety by a mixing model concept application. The additional objective of this study was to analyze the applicability of the commercial HTP probe for the determination volumetric heat capacity $\left(C_{v}\right)$ of degraded organic materials from the upper soil profile layers, compared to that obtained with the mixing model.

\section{Materials and Methods}

\subsection{Overview of Investigation Area and Measurement Procedures}

The investigation of thermal properties was performed in two independent stages. In the first stage, the specific heat capacity $\left(c_{p}\right)$ was measured for selected peat and moorsh soils commonly appearing in drained peatlands in Poland. The disturbed soil samples were collected from 18 soil layers at six different sites and prepared for the MDSC measurements (Table 1). The majority of sites were located in the drained part of the Biebrza Valley basin $\left(22^{\circ} 30^{\prime}-23^{\circ} 60^{\prime} \mathrm{E}\right.$ and $\left.53^{\circ} 30^{\prime}-53^{\circ} 75^{\prime} \mathrm{N}\right)$. In this region five drained soil profiles were selected, from which 16 soil layers were sampled for the $c_{p}$ determination. Two additional soil layers were investigated from a soil profile located in the northern part of Poland by the Baltic Sea $\left(17^{\circ} 31^{\prime} \mathrm{E}\right.$ and $\left.54^{\circ} 41^{\prime} \mathrm{N}\right)$. This area is currently being regenerated following peat mining. Within studied soil profiles, the peat soil layers were classified [41], depending on the kind of organic materials, as fibric (at sites 6), hemic (sites 1, 2, 4, and 5) and sapric (site 3) Histosols. The surface layers (approximately $0-25 \mathrm{~cm}$ ) are referred to as muck (moorsh), in accordance to the Soil Survey Manual [42], to emphasize the degradation process of the upper soil layers following former drainage (sites 1-5). In addition to these disturbed samples, undisturbed soil samples were also collected in triplicates for basic soil properties determination.

The second stage of the investigation was focused on the evaluation of the volumetric heat capacity determined using the mixing model [12] and a heat temperature probe (HTP) [43]. The $C_{v}$ measurements were conducted for the upper soil layers (moorsh) on undisturbed samples at the selected sites in the Biebrza Valley basin (the soil profiles indicated as 1, 2, 3, 4, and 5 in Table 1). The measurement methods are described in the next sections.

\subsection{Soil Basic Properties}

The collected soil cores were sealed with a rubber cover at both ends and packed into thermal plastic bags to avoid water loss through evaporation. Under laboratory conditions, each soil sample was weighed, and oven dried at $105^{\circ} \mathrm{C}$ for $24 \mathrm{~h}$ after air drying. Soil bulk density $\left(\rho_{b}\right)$ was calculated by dividing the oven-dry sample weight by the core volume $\left(100 \mathrm{~cm}^{3}\right)$. Gravimetric soil moisture content $\left(\theta_{m}\right)$ was calculated for each sample and then converted to volumetric moisture content $\left(\theta_{v}\right)$ using $\rho_{b}$. The specific soil particle density $\left(\rho_{p}\right)$ of the soils was calculated following [1] by assuming that an increase of ash content of about $1 \%$ causes an increase in $\rho_{p}$ of about $0.011 \mathrm{~g} \mathrm{~cm}^{-3}$ from the nominal value of $1.451 \mathrm{~g} \mathrm{~cm}^{-3}$. Organic carbon content (C) was determined spectrophotometrically [44] and total $\mathrm{N}$ content was measured by Kjeldahl's method; then the $\mathrm{C}: \mathrm{N}$ ratio was calculated. The 
ash content was derived from soil organic matter content (SOM) content as the mass of residue following loss on ignition [34]. For this reason, the disturbed sub-samples were ignited in a muffle furnace at $550{ }^{\circ} \mathrm{C}$ for $4 \mathrm{~h}$. Soil porosity $\left(P_{o}\right)$ was calculated using values of soil bulk density and soil particle density. Basic soil physical and chemical properties are presented in Table 1.

Table 1. Sites coordinates and soil basic properties.

\begin{tabular}{|c|c|c|c|c|c|c|c|c|c|c|c|}
\hline $\begin{array}{c}\text { Site } \\
\text { Coordinates }\end{array}$ & Site_ID & $\begin{array}{c}\text { Soil } \\
\text { Layer }\end{array}$ & $\begin{array}{l}\text { Thickness } \\
\text { (cm) }\end{array}$ & Soil Type & $\begin{array}{c}\mathrm{C} \\
(\%)\end{array}$ & $\begin{array}{c}N \\
(\%)\end{array}$ & $\begin{array}{c}\text { C:N } \\
(-)\end{array}$ & $\begin{array}{l}\mathrm{AC} \\
(\%)\end{array}$ & $\begin{array}{c}\rho_{b} \\
\left(\mathrm{~g} \mathrm{~cm}^{-3}\right)\end{array}$ & $\begin{array}{c}\rho_{p} \\
\left(\mathrm{~g} \mathrm{~cm}^{-3}\right)\end{array}$ & $\begin{array}{c}P_{o} \\
\left(\mathrm{~cm}^{3} \mathrm{~cm}^{-3}\right.\end{array}$ \\
\hline N 53.6306 & \multirow[t]{3}{*}{ Site1 } & P1 & 00-15 & Moorsh & 39.00 & 3.30 & 11.82 & 19.24 & 0.3441 & 1.6626 & 0.7930 \\
\hline \multirow[t]{2}{*}{ Е 22.7388} & & P2 & $45-50$ & Reed & 43.27 & 2.71 & 15.97 & 13.52 & 0.1620 & 1.5997 & 0.8987 \\
\hline & & P3 & $75-80$ & Reed & 48.88 & 2.40 & 20.37 & 10.75 & 0.1350 & 1.5693 & 0.9140 \\
\hline N 53.6082 & \multirow[t]{3}{*}{ Site2 } & $\mathrm{P} 4$ & 00-15 & \multirow{3}{*}{$\begin{array}{c}\text { Moorsh } \\
\text { Sedge- } \\
\text { Reed } \\
\text { Reed }\end{array}$} & 42.06 & 2.99 & 14.07 & 19.01 & 0.3397 & 1.6601 & 0.7954 \\
\hline \multirow[t]{2}{*}{ E 22.6349} & & P5 & $45-50$ & & 44.63 & 2.83 & 15.77 & 11.58 & 0.1559 & 1.5784 & 0.9012 \\
\hline & & P6 & $75-80$ & & 45.04 & 2.11 & 21.35 & 10.95 & 0.1489 & 1.5715 & 0.9052 \\
\hline N 53.6507 & \multirow[t]{4}{*}{ Site3 } & P7 & 00-15 & Moorsh & 40.05 & 3.10 & 12.92 & 21.15 & 0.3047 & 1.6837 & 0.8190 \\
\hline \multirow{3}{*}{ E 22.5779} & & P8 & $22-32$ & Alder & 43.41 & 3.07 & 14.14 & 13.26 & 0.1944 & 1.5969 & 0.8783 \\
\hline & & P9 & $45-60$ & Alder & 42.06 & 3.36 & 12.52 & 14.85 & 0.1894 & 1.6144 & 0.8827 \\
\hline & & P10 & $75-80$ & Alder & 40.03 & 2.81 & 14.25 & 17.46 & 0.2204 & 1.6431 & 0.8659 \\
\hline N 53.7007 & \multirow[t]{3}{*}{ Site4 } & P11 & 05-15 & \multirow{3}{*}{$\begin{array}{l}\text { Moorsh } \\
\text { Sedge- } \\
\text { Moss } \\
\text { Sedge- } \\
\text { Moss }\end{array}$} & 38.95 & 2.63 & 14.81 & 19.78 & 0.1803 & 1.6686 & 0.8919 \\
\hline \multirow[t]{2}{*}{ E 22.6456} & & P12 & $15-30$ & & 41.12 & 2.34 & 17.57 & 16.15 & 0.1785 & 1.6287 & 0.8904 \\
\hline & & P13 & $40-50$ & & 49.50 & 2.92 & 16.95 & 10.60 & 0.1326 & 1.5676 & 0.9154 \\
\hline N 53.7023 & \multirow[t]{3}{*}{ Site5 } & P14 & 00-10 & Moorsh & 26.39 & 2.00 & 13.20 & 31.59 & 0.2507 & 1.7985 & 0.8606 \\
\hline \multirow[t]{2}{*}{ E 22.4130} & & P15 & $10-20$ & Moorsh & 27.90 & 2.10 & 13.29 & 25.04 & 0.2307 & 1.7264 & 0.8664 \\
\hline & & P16 & $50-60$ & $\begin{array}{l}\text { Sedge- } \\
\text { Reed }\end{array}$ & 47.64 & 3.20 & 14.89 & 10.01 & 0.1443 & 1.5611 & 0.9076 \\
\hline N 54.6987 & \multirow[t]{2}{*}{ Site6 } & P17 & $0-10$ & Moss & 50.56 & 1.10 & 45.96 & 2.00 & 0.0587 & 1.4730 & 0.9601 \\
\hline E 17.5210 & & P18 & $10-20$ & Moss & 51.96 & 1.40 & 37.11 & 2.50 & 0.0702 & 1.4785 & 0.9525 \\
\hline \multirow{3}{*}{\multicolumn{4}{|c|}{ Basic statistic measures }} & Min & 26.39 & 1.10 & 11.82 & 2.00 & 0.0587 & 1.4730 & 0.7930 \\
\hline & & & & Max & 51.96 & 3.36 & 45.96 & 31.59 & 0.3441 & 1.7985 & 0.9601 \\
\hline & & & & AVG & 42.36 & 2.58 & 18.16 & 14.97 & 0.1911 & 1.6157 & 0.8832 \\
\hline
\end{tabular}

C—organic carbon content, N-total nitrogen content, AC—ash content, $\rho_{b}$ - soil bulk density, $\rho_{p}$-particle density, $P_{0}$ - porosity.

\subsection{Specific Heat Capacity Measurements}

The soil preparation for the $c_{p}$ measurements followed the methodology described by DeLapp and LeBoeuf (2004) [20]. The disturbed soil samples were crushed, sieved using a $250 \mathrm{~mm}$ sieve, and then reduced to a fine powder in a mortar and pestle. Each sample was placed in a desiccator before analysis. The MDSC experiments were performed on a TA Instrument Q200 differential scanning calorimeter (New Castle, DE, USA). The cell was purged with $50 \mathrm{~mL} \mathrm{~min}{ }^{-1}$ dry nitrogen and calibrated for baseline on an empty oven and for temperature using a pure indium standard [45]. The specific heat capacity $\left(c_{p}\right)$ was calibrated using a sapphire. An empty sealed aluminum pan was used as a reference in each test. Peat powders (7-13 mg) were non-hermetically sealed in aluminum pans (volume $30 \mu \mathrm{L}$ ). The change in heat capacity, $\Delta c_{p}$, was determined by taking the heat capacity difference between the temperature $-20^{\circ} \mathrm{C}$ to $30^{\circ} \mathrm{C}$. The quasi-isothermal runs were done in the modulated mode using an amplitude of $\pm 0.30{ }^{\circ} \mathrm{C}$, a period of $120 \mathrm{~s}$, and an incremental step of $5{ }^{\circ} \mathrm{C}$. Measurements were conducted at 5 min intervals. Each measurement lasted $5 \mathrm{~min}$ (Figure 1). The measurements were done in two replicates for each sample. The $c_{p}$ was measured at the beginning and end of a time interval for each temperature (Figure 1). Consequently, the average $c_{p}$ for each temperature was determined from the four $c_{p}$ values (two values at each temperature in two soil replications). The results of average specific heat capacity with standard deviations at each temperature for whole investigated dataset are included in Supplementary Materials (Table S1). 


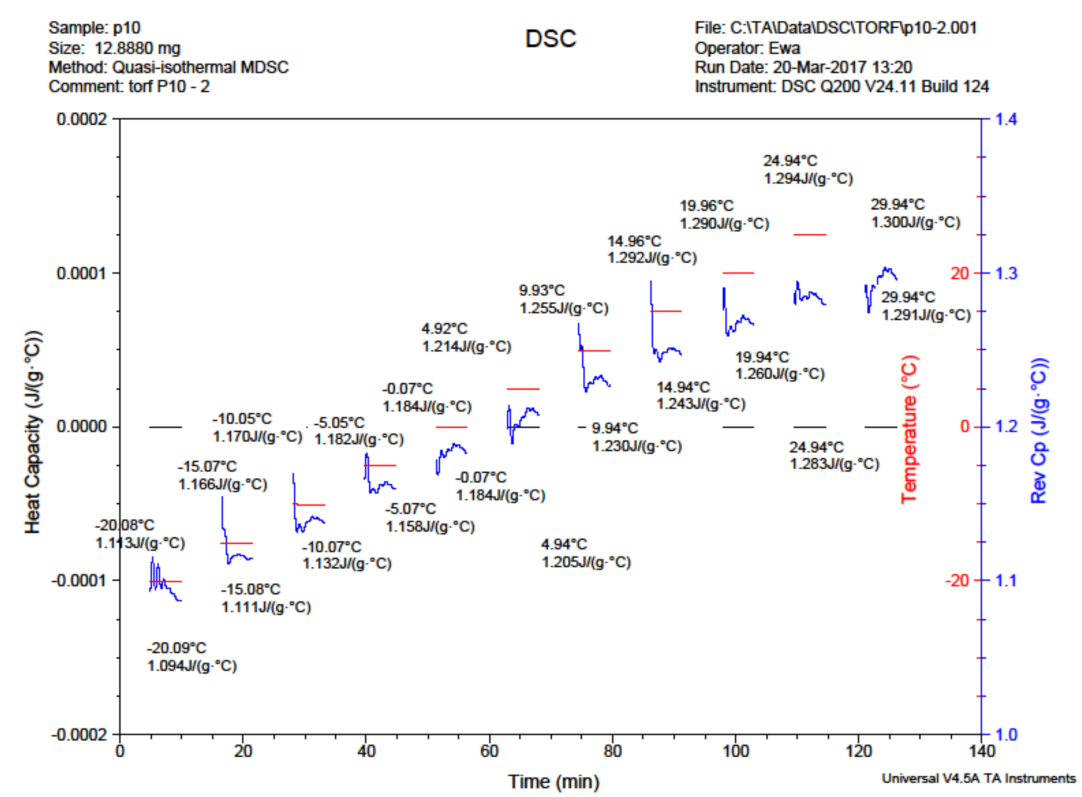

Figure 1. Example of the MDSC results of the specific heat capacity measurements.

\subsection{Volumetric Heat Capacity}

The volumetric heat capacity ( $C_{v}$ data) of the moorsh (muck) layers were measured on undisturbed samples to characterize the functional relationships between $C_{v}$ and moisture content $\left(\theta_{v}\right)$. A portable thermal properties analyzer KD2-Pro Decagon with a SH-1 dualneedle probe was used [43]. The principles of this measurement system rely on heat conduction analysis from a transient line heat source [13,21,22]. In the measurement system heat is applied to one of the needles ( $30 \mathrm{~mm}$ long) for a set time while in the second needle, which is placed in parallel at a $6 \mathrm{~mm}$ distance, the temperature response is monitored. Based on the set of temperature measurements taken at $1 \mathrm{~s}$ intervals during a $30 \mathrm{~s}$ heating period and a $30 \mathrm{~s}$ cooling period, and using the solution for radial conduction from an infinite line source $[22,46]$ the KD2 Pro, with SH-1 dual-needle probe, determined the soil thermal properties (i.e., volumetric heat capacity $(C v)$, thermal conductivity $(\lambda)$, and thermal diffusivity $(D)$. The basic theory of the KD2 Pro system [43] is described in the study by Mengistu et al. (2017) [47]. Similar commercial measurement systems have been used for the determination of the thermal properties of ombrotrophic peat soils [39] as well as for moss peats [38].

The undisturbed soil samples were collected into vertically oriented standard cores in triplicate (100 $\mathrm{cm}^{3}$ volume) from the depths $5 \mathrm{~cm}, 7.5 \mathrm{~cm}, 12.5 \mathrm{~cm}$, and $22.5 \mathrm{~cm}$. Different depths of soil collection was chosen to ensure soil moisture gradients. The samples were taken out from the soil profiles at sites 1, 2, and 4 during one field campaign on 17 June 2016 whereas the soil profile at site 3 was sampled on 17 April 2015. Additional samples at sites 3 and 5 were taken in late autumn 2015. In total, sampling was done 22 times in triplicate for the distinct depths (66 soil cores). SH-1 dual-needle probe, of the KD2 Pro system, was installed vertically in each soil sample from the top surface and then thermal properties were measured. The bottom end of the core was covered. According to the Decagon Devices Inc manual, no specific calibration of the measurement system was required. Nevertheless, thermal readings were performed in a Darlin block and compared with the range included in the quality assurance Certificate provided by the manufacturer [43]. The thermal measurements using the $\mathrm{SH}-1$ probe were done at one-hour intervals to avoid overheating of the probe. For each soil sample, the volumetric moisture content and soil bulk density was determined as described in the section on basic soil properties. 


\subsection{Data Analysis}

\section{- $\quad$ Stage 1}

Following [19], a linear equation was used to describe the relationship between the soil temperature $(T)$ and specific heat capacity $\left(c_{p}\right)$ :

$$
c_{p}(T)=C_{0}+C_{1} \cdot T+\varepsilon
$$

The intercept $C_{0}$ indicates the specific heat capacity $c_{p}\left(\mathrm{~J} \mathrm{~g}^{-1} \mathrm{~K}^{-1}\right)$ at temperature $0{ }^{\circ} \mathrm{C}$. The slope $C_{1}$ represents the amount of change in specific heat capacity per $1^{\circ} \mathrm{C}$ change in temperature. The $\varepsilon$ is an array of probabilistic random errors ( $e_{i}$ residuals).

Subsequently, the empirical relationship between these specific heat capacity predictors $\left(C_{0}\right.$ and $\left.C_{1}\right)$ and the soil basic properties (Table 1$)$ was studied using a correlation matrix and linear and polynomial regressions. The general form of the empirical model which includes independent variables can be written as:

$$
Y=\beta_{0}+\beta_{1} X_{1}+\beta_{2} X_{2}+\ldots+\beta_{k} X_{k}+\varepsilon
$$

The dependent variable $Y$, representing $C_{0}$ and $C_{1}$, can be written as a function of $k$ independent variables $X_{1}, X_{2}, \ldots, X_{k}$. The $X_{i}$ values represent a set of explanatory variables regarding chemical and physical soil properties (Table 1 ). An ordinary least square method was used to determine the equations for predicting $C_{0}$ and $C_{1}$. The evaluation of the empirical equations was performed using the following statistics: coefficient of determination $\left(R^{2}\right)$, adjusted coefficient of determination $\left(R^{2}\right.$ adj.), root mean square error (RMSE), and cross-validated error $\left(\mathrm{RMSE}_{\mathrm{CV}}\right)$. The cross-validation was done using a leave-one-out scheme. The statistical analysis and graphics were performed in the $\mathrm{R}$ environment [48].

\section{- $\quad$ Stage 2}

The mixing model expresses $C_{v}$ as a function of solid and water constituents and can be written as [12]:

$$
C_{v}\left(\theta_{v}\right)=c_{w} \cdot \rho_{w} \cdot \theta_{v}+c_{p}(T) \cdot \rho_{b}
$$

where $\rho_{w}$ and $\rho_{b}\left(\mathrm{~g} \mathrm{~cm}^{-3}\right)$ are the water and soil dry bulk densities, respectively, $\theta_{v}$ is the volumetric water content $\left(\mathrm{cm}^{3} \mathrm{~cm}^{-3}\right), c_{w}$ and $c_{p}$ are specific heat capacity of water and solid phase $\left(\mathrm{J} \mathrm{g}^{-1} \mathrm{~K}^{-1}\right)$. We used a variation of Equation (3) where the $c_{w}, c_{p}$ represents temperature-dependent moorsh-specific data and $\theta_{v}$ and $\rho_{b}$ have sample-specific values. The influence of the water temperature $(T)$ on its specific heat capacity $\left(\mathrm{J} \mathrm{g}^{1} \mathrm{~K}^{-1}\right)$ was accounted for using Roberts formula [19]:

$$
c_{w}(T)=4.2048-0.001768 \cdot T+0.00002645 \cdot T^{2}
$$

Thus, if these parameters are known from independent measurements $\left(c_{p}, \rho_{b}\right)$ or estimated $\left(c_{w}\right), C_{v}$ can be determined with Equation (3) for any given moisture content and the results can be compared with independently measured value using the HTP.

\section{Results}

\subsection{Heat Capacity Data}

\subsubsection{Specific Heat of Investigation Organic Soils}

Figure 2 presents the data set of temperature-dependent specific heat capacity values obtained experimentally for the peat-moorsh soil profiles. The lowest measured values were observed for the lightly decomposed (H1-H2) moss peats (P17 and P18) according to von Post scale. Conversely, the highly decomposed (H7) alder peats (P8-P10) had the highest specific heat capacity values. Relatively similar heat capacity data were observed for the group including sedge soil layers (P5, P12, P13 and P16) with moderate soil organic matter decomposition ( $\mathrm{H} 2-\mathrm{H} 5)$. The $c_{p}$ data were highly variable in the group comprising 
upper soil layers (P1, P4, P7, P11, P14, and P15). The fitting lines at Figure 2 present the average linear relationships between specific heat capacity $\left(c_{p}\right)$ and temperature $(T)$ for each distinct soil group.
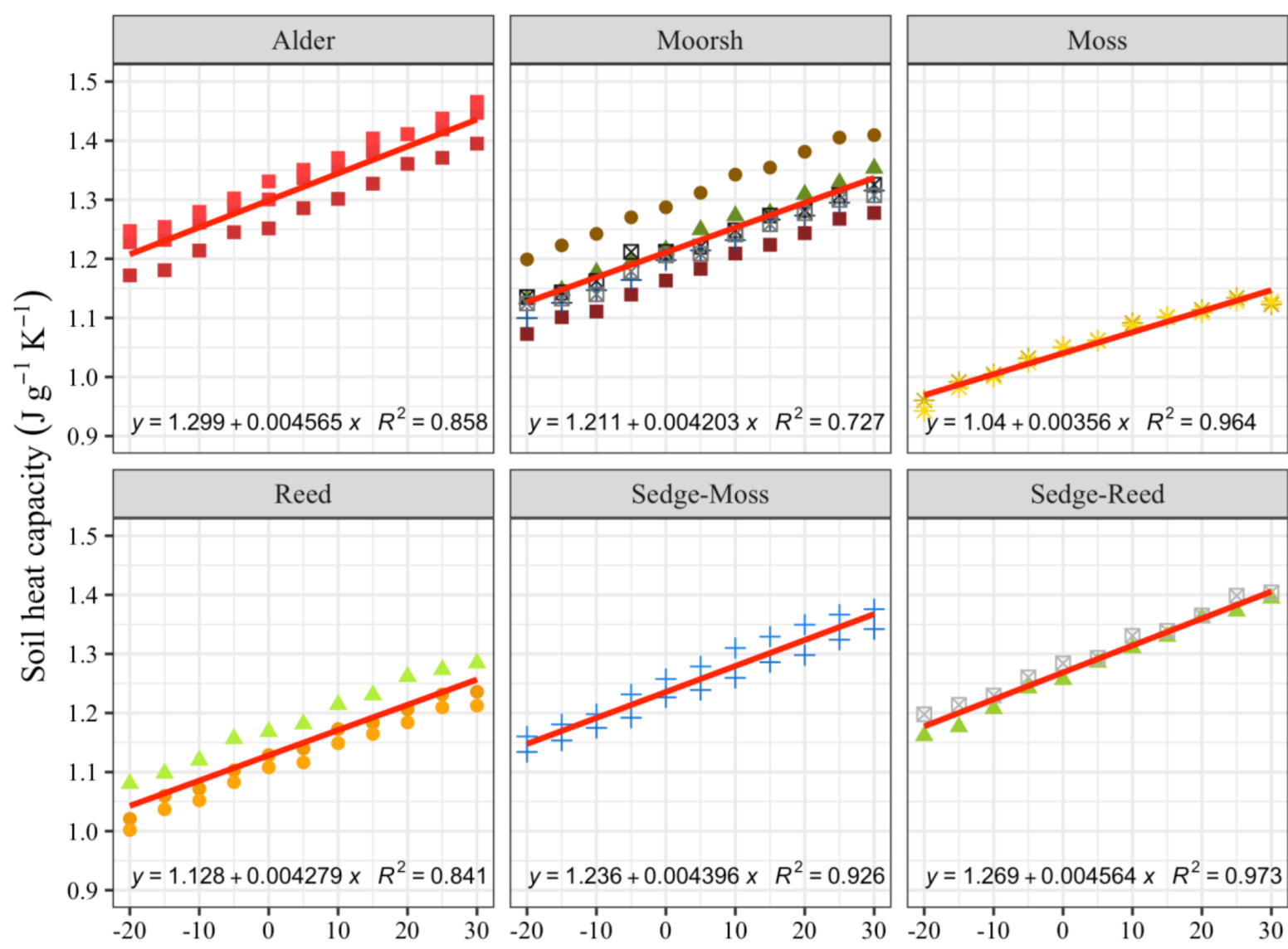

Soil layers

- P1

- P2

- P3

- P4

- P5

- P6

- $\mathrm{P} 7$

- P8

- P9

- P10

- P11

- P12
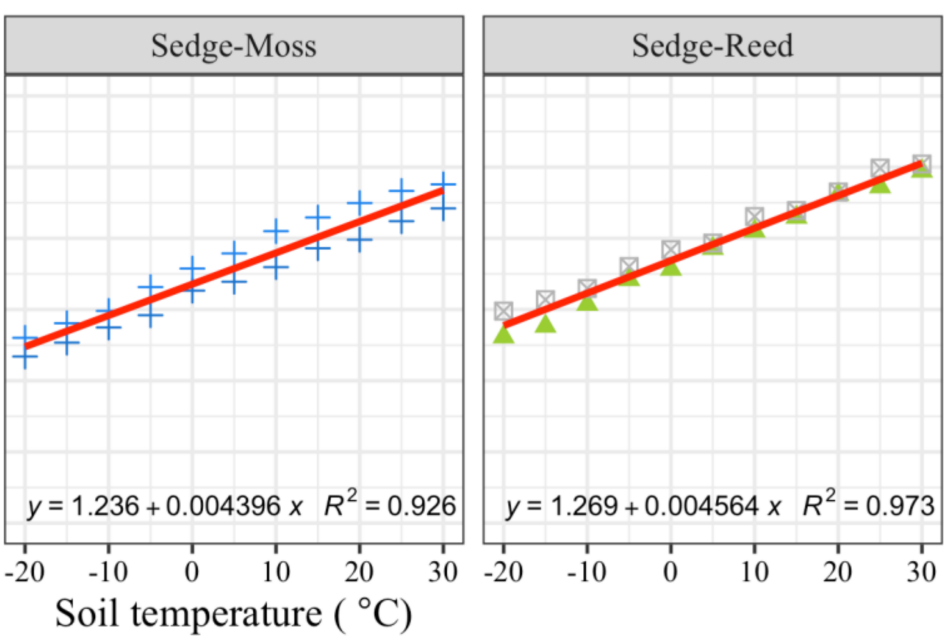

- P13

- P14

- P15

- P16

- P17

- P18

Sites

- Site 1

- Site2

- Site 3

+ Site4

$\otimes$ Site5

* Site6

Figure 2. Temperature-dependent soil specific heat capacity characteristics for the 18 soil layers analyzed, grouped by organic matter origin. Colors and shapes indicate the different soil layers and sites according to the data presented in Table 1 . The equation parameters indicate the intercept $\left(C_{0}\right)$ and slope $\left(C_{1}\right)$. Y represents $c_{p}$ and $\mathrm{X}$ is soil temperature.

For each soil layer, the parameters of the linear Equation (1) were determined and included in Table 2 with basic statistical measures of the quality of the fit. The $C_{0}$ parameter varied from approximately 1.040 to $1.330 \mathrm{~J} \mathrm{~g}^{-1} \mathrm{~K}^{-1}$ with a mean value of $1.202 \mathrm{~J} \mathrm{~g}^{-1} \mathrm{~K}^{-1}$. The slope value, $C_{1}$, representing the change in specific heat capacity for a $1^{\circ} \mathrm{C}$ change in temperature, ranged from 0.0034 to $0.0048 \mathrm{~J} \mathrm{~g}^{-1} \mathrm{~K}^{-1}$ with a mean value of $0.0043 \mathrm{~J} \mathrm{~g}^{-1} \mathrm{~K}^{-1}$ for the 18 soil layers studied. It should be stressed that both linear parameters $\left(C_{0}\right.$ and $\left.C_{1}\right)$ were the smallest in the moss peats $(\mathrm{P} 17, \mathrm{P} 18)$. The maximum $C_{0}$ value was obtained for the alder peat (P10), whereas the highest slope estimator occurred in the sedge-reed peat (P5). Figure 3 illustrates the performance of the linear equations in predicting the measured data. For both cases the $c_{p}$ values calculated using the linear equation and leave-out-one scheme were similar to the measured data as shown by a comparison line close to unity. 
Table 2. Descriptive statistics of fitted lines of $c_{p}(T)$ relationships.

\begin{tabular}{|c|c|c|c|c|c|c|c|c|c|c|}
\hline $\begin{array}{c}\text { Soil } \\
\text { Layer }\end{array}$ & Type of Soil & $C_{0}$ & $C_{1}$ & $C_{0 s e}$ & $C_{1 s e}$ & $p$-Value & $\mathbf{R}^{2}$ & $\sigma$ & $\mathrm{RMSE}_{\mathrm{lm}}$ & RMSE $_{\text {cv }}$ \\
\hline P1 & Moorsh & 1.289 & 0.004406 & $1.835 \times 10^{-3}$ & $1.11 \times 10^{-4}$ & $1.98 \times 10^{-11}$ & 0.9943 & 0.00580 & 0.005249 & 0.006977 \\
\hline P2 & Reed & 1.119 & 0.004315 & $2.574 \times 10^{-3}$ & $1.55 \times 10^{-4}$ & $4.90 \times 10^{-10}$ & 0.9885 & 0.00814 & 0.007363 & 0.009829 \\
\hline P3 & Reed & 1.098 & 0.004262 & $2.491 \times 10^{-3}$ & $1.50 \times 10^{-4}$ & $4.09 \times 10^{-10}$ & 0.9889 & 0.00788 & 0.007127 & 0.009532 \\
\hline $\mathrm{P} 4$ & Moorsh & 1.219 & 0.004458 & $1.779 \times 10^{-3}$ & $1.07 \times 10^{-4}$ & $1.35 \times 10^{-11}$ & 0.9948 & 0.00563 & 0.005089 & 0.005867 \\
\hline P5 & Sedge-Reed & 1.257 & 0.004796 & $1.948 \times 10^{-3}$ & $1.17 \times 10^{-4}$ & $1.58 \times 10^{-11}$ & 0.9946 & 0.00616 & 0.005573 & 0.007028 \\
\hline P6 & Reed & 1.167 & 0.004259 & $2.176 \times 10^{-3}$ & $1.31 \times 10^{-4}$ & $1.23 \times 10^{-10}$ & 0.9915 & 0.00688 & 0.006223 & 0.007759 \\
\hline P7 & Moorsh & 1.160 & 0.004188 & $1.567 \times 10^{-3}$ & $9.45 \times 10^{-5}$ & $7.56 \times 10^{-12}$ & 0.9954 & 0.00495 & 0.004481 & 0.005790 \\
\hline P8 & Alder & 1.259 & 0.004601 & $2.063 \times 10^{-3}$ & $1.24 \times 10^{-4}$ & $3.83 \times 10^{-11}$ & 0.9935 & 0.00653 & 0.005902 & 0.007219 \\
\hline P9 & Alder & 1.309 & 0.004612 & $2.141 \times 10^{-3}$ & $1.29 \times 10^{-4}$ & $5.22 \times 10^{-11}$ & 0.9929 & 0.00677 & 0.006124 & 0.007891 \\
\hline $\mathrm{P} 10$ & Alder & 1.328 & 0.004482 & $1.803 \times 10^{-3}$ & $1.09 \times 10^{-4}$ & $1.45 \times 10^{-11}$ & 0.9947 & 0.00570 & 0.005156 & 0.006641 \\
\hline P11 & Moorsh & 1.190 & 0.004315 & $1.724 \times 10^{-3}$ & $1.04 \times 10^{-4}$ & $1.36 \times 10^{-11}$ & 0.9948 & 0.00545 & 0.004931 & 0.005889 \\
\hline $\mathrm{P} 12$ & Sedge-Moss & 1.218 & 0.004205 & $1.279 \times 10^{-3}$ & $7.71 \times 10^{-5}$ & $1.18 \times 10^{-12}$ & 0.9969 & 0.00405 & 0.003659 & 0.004214 \\
\hline $\mathrm{P} 13$ & Sedge-Moss & 1.253 & 0.004587 & $2.472 \times 10^{-3}$ & $1.49 \times 10^{-4}$ & $1.98 \times 10^{-10}$ & 0.9906 & 0.00782 & 0.007072 & 0.009171 \\
\hline P14 & Moorsh & 1.209 & 0.003871 & $2.863 \times 10^{-3}$ & $1.73 \times 10^{-4}$ & $3.31 \times 10^{-09}$ & 0.9824 & 0.00906 & 0.008190 & 0.009592 \\
\hline P15 & Moorsh & 1.196 & 0.003981 & $2.621 \times 10^{-3}$ & $1.58 \times 10^{-4}$ & $1.18 \times 10^{-09}$ & 0.9860 & 0.00829 & 0.007497 & 0.009321 \\
\hline P16 & Sedge-Reed & 1.279 & 0.004331 & $2.079 \times 10^{-3}$ & $1.25 \times 10^{-4}$ & $7.04 \times 10^{-11}$ & 0.9925 & 0.00657 & 0.005946 & 0.007339 \\
\hline $\mathrm{P} 17$ & Moss & 1.043 & 0.003434 & $3.520 \times 10^{-3}$ & $2.12 \times 10^{-4}$ & $5.84 \times 10^{-08}$ & 0.9667 & 0.01113 & 0.010068 & 0.013759 \\
\hline P18 & Moss & 1.037 & 0.003687 & $3.809 \times 10^{-3}$ & $2.30 \times 10^{-4}$ & $6.25 \times 10^{-08}$ & 0.9662 & 0.01205 & 0.010896 & 0.014782 \\
\hline
\end{tabular}

$C_{0}$ and $C_{1}$-fitting line parameters of the $c_{p}(T)$ relationship (Equation (1)), $C_{0 s e}$ and $C_{1 s e}$-standard errors of the parameters, $p$-value $<0.05$ indicates statistical importance of equation, $\mathrm{R}^{2}$-coefficient of determination, $\sigma$-standard error of residuals, $\mathrm{RMSE}_{\mathrm{lm}}, \mathrm{RMSE}_{\mathrm{cv}}$-root mean square error relating to the average error of $c_{p}$ estimation using line parameters and based on leave-out-one procedure, respectively.
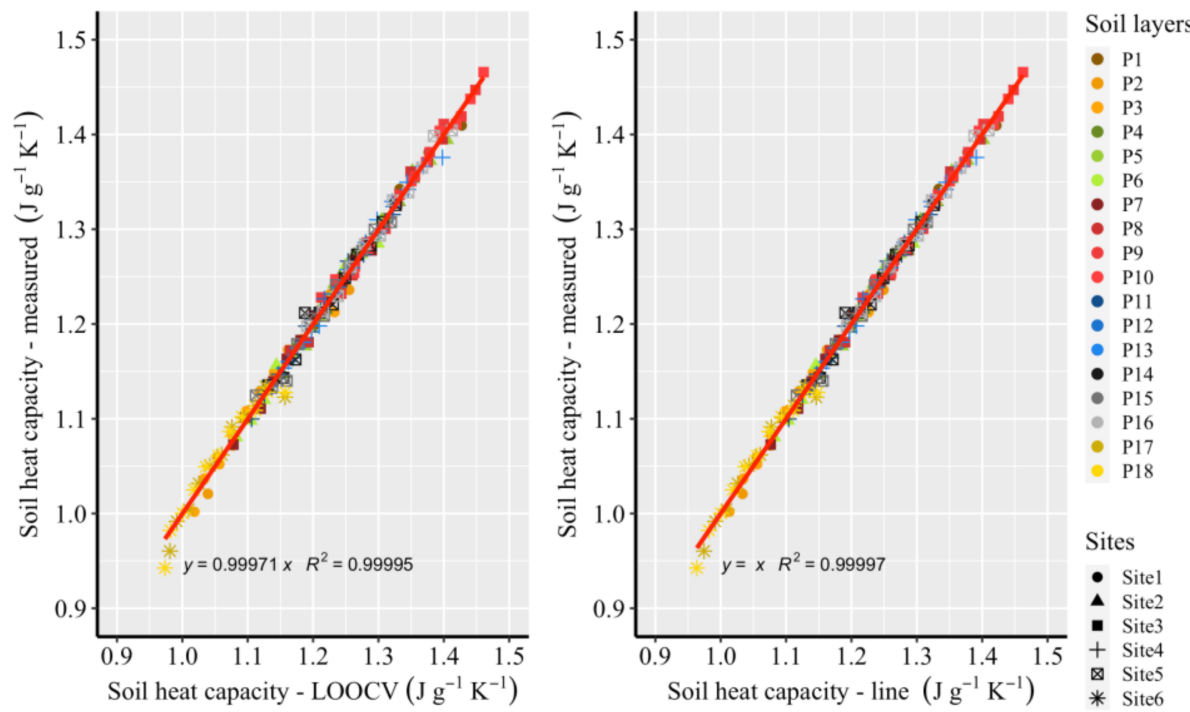

Figure 3. Predicted vs. measured specific heat capacity data. The left-hand graph shows comparison between calculated data using a leave-out-one cross-validation scheme (LOOCV) and measured $c_{p}$ data. The right-hand graph data shows comparison between linear prediction (line) and measured $c_{p}$ data.

The data presented in Figure 3 and Table 2 suggest that higher errors in the $c_{p}(T)$ estimation are determined for moss peats when compared to the $c_{p}(T)$ error prediction of the other soils. The results obtained indicate that the $C_{0}$ and $C_{1}$ parameter significantly explains the relationship between soil temperature and specific heat capacity data. Hence, the further analysis of the $c_{p}(T)$ data was focused on establishing statistical equations enabling prediction of the line parameters $\left(C_{0}\right.$ and $\left.C_{1}\right)$ based on the soil chemical and physical properties. 


\subsubsection{Volumetric Heat Capacity Data and Soil Physical Properties}

Figure 4 illustrates the variation in the soil volumetric heat capacity data which were measured using the thermal probe. The $C_{v}$ value ranged from 1.79 to $3.84 \mathrm{~J} \mathrm{~cm}^{-3} \mathrm{~K}^{-1}$ for the analyzed soil layers (Figure 4a). At the same time, volumetric moisture content varied from $0.315 \mathrm{~cm}^{3} \mathrm{~cm}^{-3}$ to $0.870 \mathrm{~cm}^{3} \mathrm{~cm}^{-3}$ (Figure 4c). Despite the different soil origins, the changes in the $C_{v}$ value follow the changes in the soil moisture content data. Any increase in the soil moisture causes an increase in the volumetric heat capacity [39]. Figure $4 \mathrm{~b}$ shows the soil temperature measurements. This part of the measurements was done in the summer where temperature varied from $21.5^{\circ} \mathrm{C}$ to $24.2{ }^{\circ} \mathrm{C}$. The rest of the samples were collected in the late autumn, so the soil temperatures were much lower and depending on the site were equal in average, i.e., $16.2{ }^{\circ} \mathrm{C}$ for site 3 and $11^{\circ} \mathrm{C}$ for site 5 . The soil bulk density $\left(\rho_{b}\right)$ oscillated between $0.114 \mathrm{~g} \mathrm{~cm}^{-3}$ to $0.351 \mathrm{~g} \mathrm{~cm}^{-3}$. However, this value in general was lowest in the soil from site 4 where, regardless of depth, it did not exceed $0.180 \mathrm{~g} \mathrm{~cm}^{-3}$ (Figure $4 \mathrm{~d}$ ).

The soil samples collected at the same depth had variable soil properties (Figure 4). This was especially visible in the $C_{v}$ data (Figure $4 \mathrm{a}$ ), which were clearly affected by the variably in moisture content (Figure 4c). The differences in soil bulk density [35] and variability in moisture content [49] were typical for the sites sampled (Figure 4c,d).
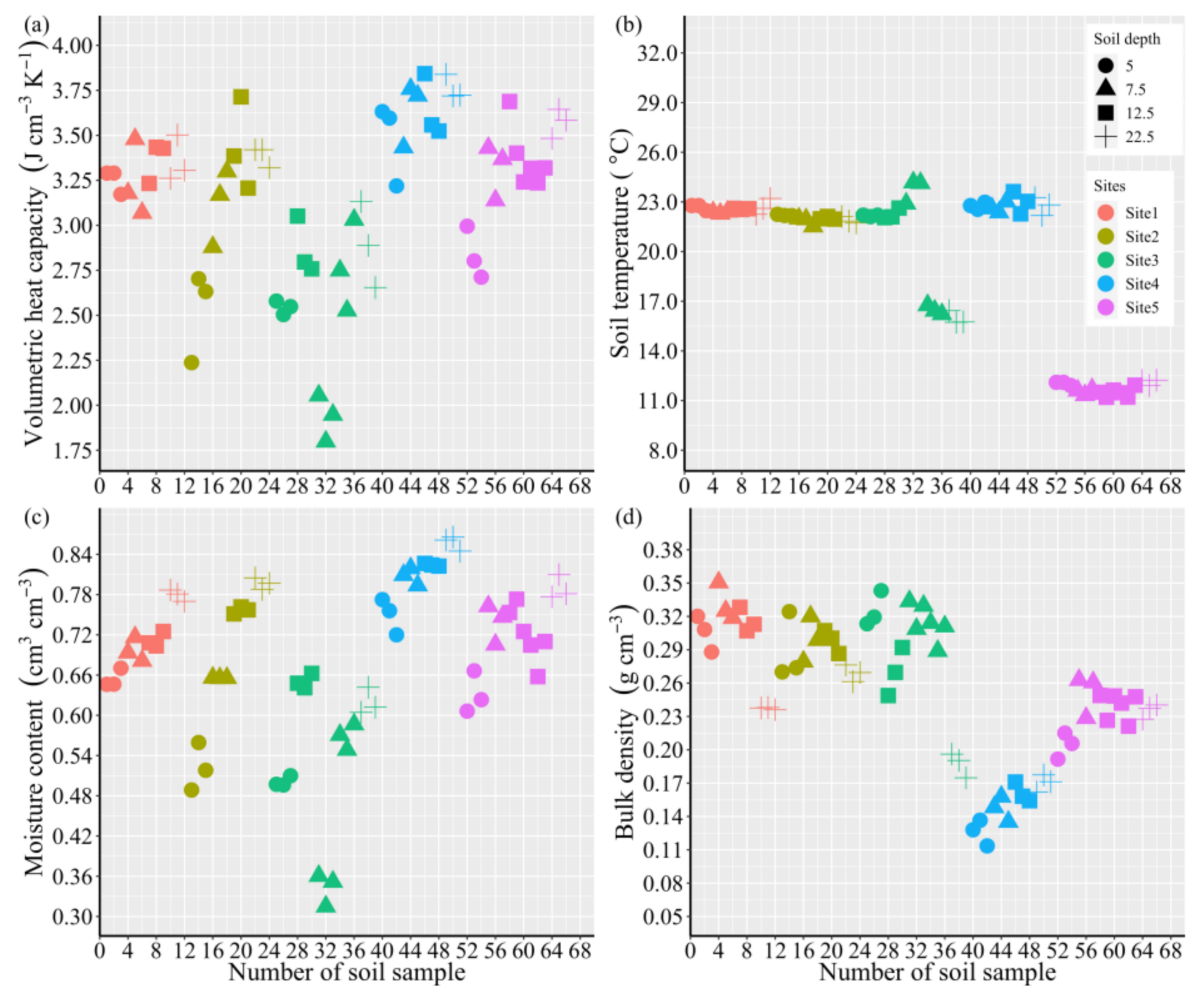

Figure 4. Results of the thermal probe (KD2 Pro) measurements (a,b) and basic soil-related properties (c,d). Soil depth in $\mathrm{cm}$.

\subsubsection{Statistical Analysis of Heat Capacity Data}

The correlation matrix graph (Figure 5) shows that $C_{0}$ and $C_{1}$ parameters were highly correlated with the soil nitrogen contents and C:N ratio. 


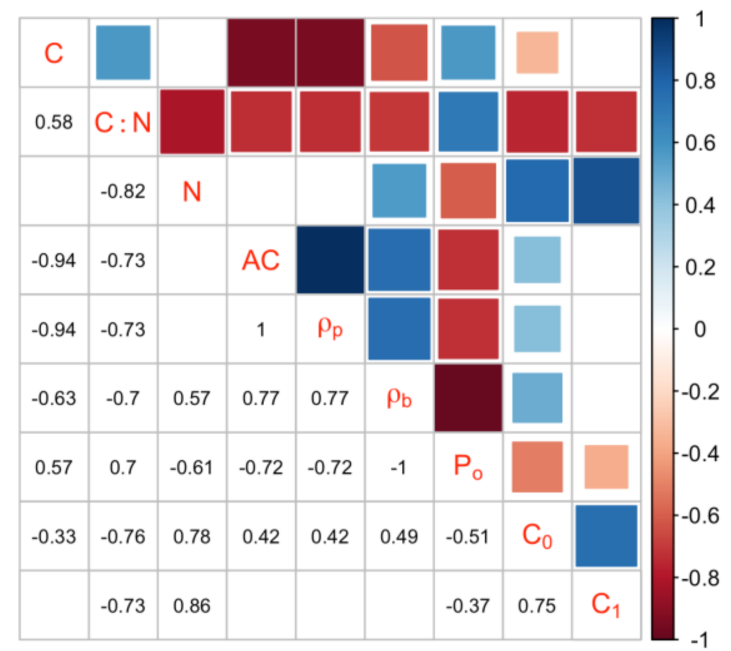

Figure 5. The Pearson correlation matrix describing the statistical relationship between soil thermal, physical, and chemical properties. The dark brown panels indicate a strong negative correlation, while a strong positive correlation between soil parameters is denoted by dark blue panels. The correlations with $p$-value $>0.05$, which are considered insignificant, are represented by white blank panel.

It was also evident that $C_{0}$ was weakly correlated to soil physical properties $\left(P_{o}, \rho_{b}\right)$ and organic carbon content $(C)$. Figure 6 illustrates the empirical relationships between selected soil properties and heat capacity parameters. In general, the data presented in Figure 6 indicate that an increase in $\mathrm{N}$ content caused an increase in both linear parameters of the $c_{p}(T)$ relation. It can be concluded that $\mathrm{N}$, one of the main soil chemical components responsible for its degradation $[6,50,51]$, importantly affects the heat capacity of peat-muck soils. Approximately $60 \%$ (detailed statistical measures are included in Table 3) of $C_{0}$ changes were explained by the linear relation with soil $\mathrm{N}$ content only. Similar results were obtained for $C_{0}$ using the $\mathrm{C}: \mathrm{N}$ ratio. The $C_{1}$ parameter could also be approximated using $\mathrm{N}$, which explains $75 \%$ of the variation of the $c_{p}(T)$ slope. The $C_{1}$ parameter could also be interpolated nonlinearly using ash content data (AC) in the range from $1.5 \%$ to $30 \%$ (Figure $6 \mathrm{~d}$ ). The quality of the prediction of the heat capacity parameters varied and a relatively weak estimation of $C_{0}$ can be expected (Table 3). Further data analysis using the ordinary least square technique shows that the prediction of the $C_{0}$ and $C_{1}$ parameters improves with the development of two- or three-variable models. The predictability for the $C_{0}$ parameter increases when considering the following three soil features: percentages of nitrogen, organic carbon, and ash content (Equation (5)). For the $C_{1}$ parameters, the prediction was improved when using C:N and AC (Equation (6)).

$$
\begin{gathered}
C_{0}=1.582+0.12491 \cdot \mathrm{N}-0.013050 \cdot \mathrm{C}-0.009981 \cdot \mathrm{AC} \\
C_{1}=5.787 \times 10^{-3}-5.115 \times 10^{-5} \cdot \mathrm{C}: \mathrm{N}-3.955 \times 10^{-5} \cdot \mathrm{AC} \\
C_{1}=5.530 \times 10^{-2}-3.553 \times 10^{-5} \cdot \mathrm{C}: \mathrm{N}-3.011 \times 10^{-2} \cdot \rho_{b}-5.053 \times 10^{-2} \cdot P_{o}
\end{gathered}
$$

The advantage of Equations (5) and (6) stems from the fact that both parameters were explained using the same type of variables representing soil chemical properties. These equations confirm that these properties had a major influence on the heat capacity data (parameters $C_{0}$ and $C_{1}$ ). Nevertheless, pairs of RMSE value (Table 3 ) indicate that the best prognostic model for the $C_{1}$ prediction was established when combining the chemical and physical properties (Equation (7)). 

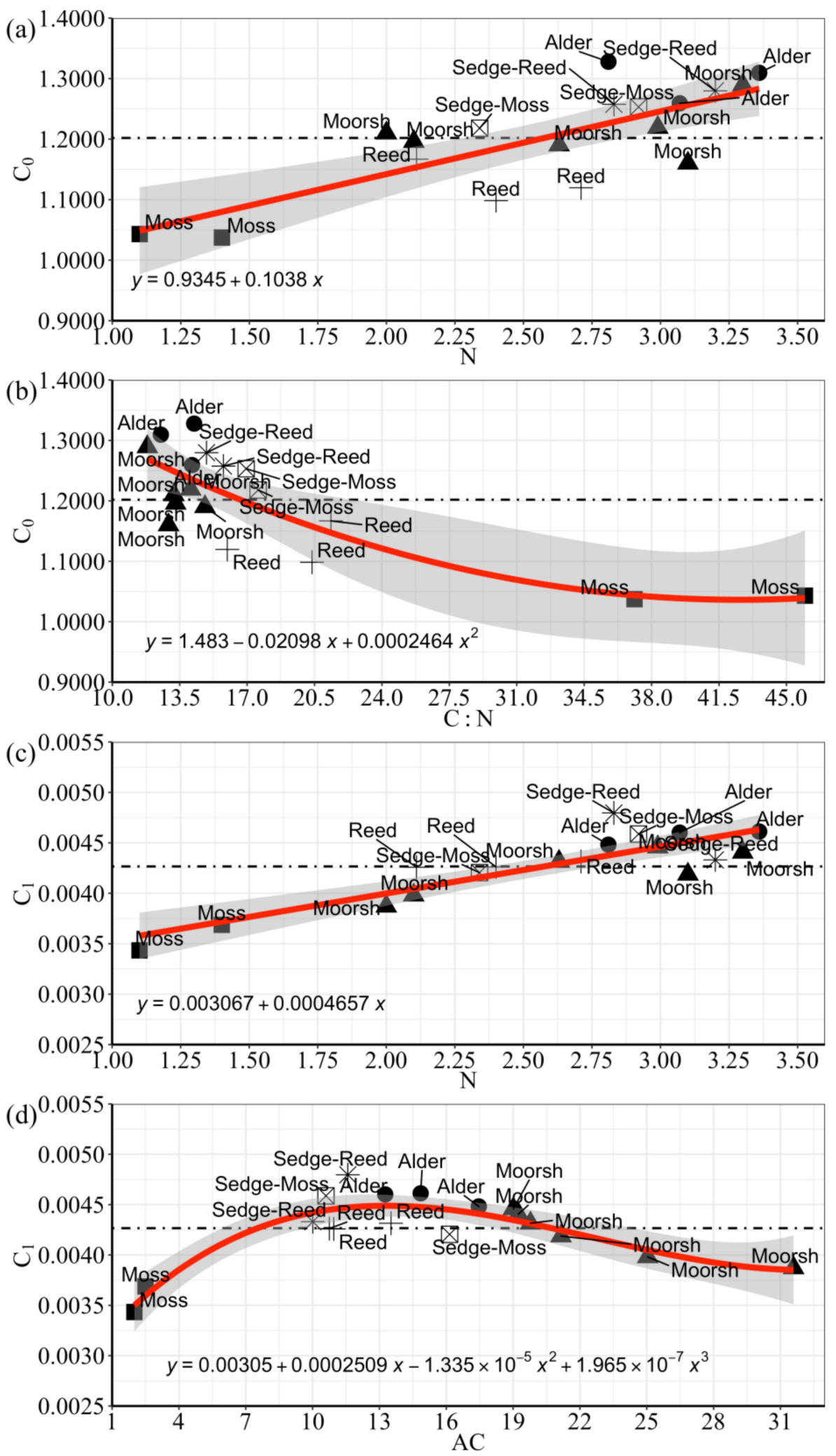

Figure 6. Empirical relationships between $c_{p}(T)$ equation parameters $C_{0}(\mathbf{a}, \mathbf{b})$ and $C_{1}(\mathbf{c}, \mathbf{d})$ and chemical properties of peat-moorsh soils. The shape of the point markers indicates the soil type. Basic descriptive statistics for the equations are given in Table 3. 
The RMSEcv value shows that when the model included the cross-correlated explanatory variables (C and $\mathrm{AC}$ in Equation (5), $\rho_{b}$ and $P_{o}$ in Equation (7)), the predicted variables $C_{0}$ and $C_{1}$ were the most certain (Table 3 ).

Table 3. Statistical measures in the $c_{p}(T)$ relationship parameters prediction.

\begin{tabular}{|c|c|c|c|c|c|c|c|}
\hline $\begin{array}{c}\text { Dependent } \\
\text { Variable }\end{array}$ & $n$ & Predictors & $\begin{array}{l}\text { Manuscript } \\
\text { Reference }\end{array}$ & $\mathbf{R}^{2}$ & $\mathbf{R}_{\text {adj. }}^{2}$ & $\mathrm{RMSE}_{\mathrm{m}}$ & RMSE $_{\text {cv }}$ \\
\hline \multirow{3}{*}{$C_{0}$} & 1 & $\mathrm{~N}$ & Figure 6a & 0.6003 & 0.5753 & 0.0524 & 0.0573 \\
\hline & 2 & $\mathrm{C}: \mathrm{N}, \mathrm{C}: \mathrm{N}^{2}$ & Figure $6 b$ & 0.6133 & 0.5617 & 0.0515 & 0.0576 \\
\hline & 3 & $\mathrm{C}, \mathrm{N}, \mathrm{AC}$ & Equation (5) & 0.7146 & 0.6535 & 0.0443 & 0.0554 \\
\hline \multirow{4}{*}{$C_{1}$} & 1 & $\mathrm{~N}$ & Figure $6 c$ & 0.7468 & 0.7310 & 0.000168 & 0.000188 \\
\hline & 3 & $\mathrm{AC}, \mathrm{AC}^{2}, \mathrm{AC}^{3}$ & Figure $6 \mathrm{~d}$ & 0.8143 & 0.7745 & 0.000144 & 0.000195 \\
\hline & 2 & $\mathrm{C}: \mathrm{N}, \mathrm{AC}$ & Equation (6) & 0.8594 & 0.8407 & 0.000125 & 0.000153 \\
\hline & 3 & $\mathrm{C}: \mathrm{N}, \rho_{b}, P_{o}$ & Equation (7) & 0.8770 & 0.8506 & 0.000117 & 0.000151 \\
\hline
\end{tabular}

$n$-number of variables in prediction model, predictors indicating independent variable as in Table 1, name of statistical measures as in Table 2. The explanatory and dependent variables were not standardized.

\subsubsection{Applicability of the $c_{p}$ Data in the Heat Capacity Mixing Model}

In the mixing model, $C_{v}$ is a function of volumetric moisture content and bulk density, but it is also affected by the influence of temperature on $c_{p}$ as well as other soil-and layerspecific properties ( $C_{0}$ and $C_{1}$ for moorsh soil Table 2$)$. Hence, the mixing model includes variables dependent on seasonality and meteorological conditions but is also affected by the variability of the chemical and physical properties of the soil system. The functional relationship between $C_{v}$ values (averaged from triplicate) and soil moisture content $\theta_{v}$ is presented in Figure 7a. Regardless of soil type (sites), the changes in the measured and calculated $C_{v}$ values with water content were very similar. The only significant discrepancies between the measured and calculated $C_{v}$ were observed for soils from sites 1 and 2 at moisture content equal to approximately $0.79 \mathrm{~cm}^{3} \mathrm{~cm}^{-3}$. The similar performance of both methods is visible in Figure $7 \mathrm{~b}$. The slope of the $C_{\text {vmixing }}-C_{\text {vmeasured }}$ relationship was equal 1.01, which indicates that the calculated value only slightly overestimated the HTP data.
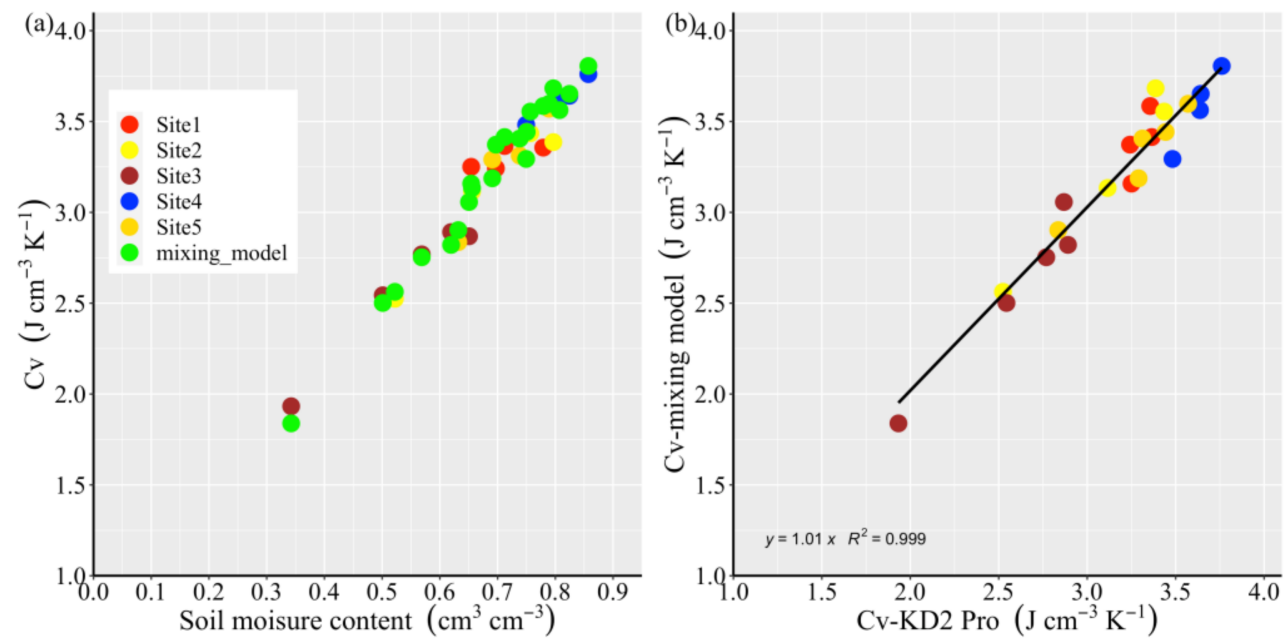

Figure 7. $C_{v}\left(\theta_{v}\right)$ relationship (a) and measured versus calculated $C_{v}$ data $(\mathbf{b})$.

\section{Discussion}

This study indicates that the specific heat capacity $\left(c_{p}\right)$ of the peat and peat-muck soils considered was linearly dependent on changes in their temperature in the range of $-20^{\circ} \mathrm{C}$ to $30^{\circ} \mathrm{C}$, similar to findings for mineral soils [19]. This temperature range was chosen for 
the MDSC experiments because it was representative of the seasonal variation to which the soil is exposed under natural conditions [52].

In this study, regardless of the temperature, the lowest $c_{p}$ values were observed in moss peats characterized by very low soil ash content. The highest $c_{p}$ values were observed in alder peats. It should be emphasized that peat groups containing sedge species were characterized by similar $c_{p}$ properties. The specific heat capacity of moorsh formations were positioned between alder and sedge-moss peats.

Peat soils belong to the group of organic materials that are characterized by a high content of organic substances, i.e., wood and coal. Hence, one may expect these specific materials of biological origin to have similar thermal properties. Since studies on the specific heat of fuel materials (wood and coal) are well documented [53-59], these can be used for comparison. The linear relationship observed in this study was very similar to the general model of specific heat prediction of wood [53]. This similarity was particularly evident in the slope, $C_{1}$, of the $c_{p}(T)$ relation (Table 4), which was 0.0043 and $0.0046 \mathrm{~J} \mathrm{~g}^{-1} \mathrm{~K}^{-1}$ on average for organic soils and wood, respectively. However, the intercepts, $C_{0}$, for organic soils $\left(1.202 \mathrm{~J} \mathrm{~g}^{-1} \mathrm{~K}^{-1}\right)$ and wood $\left(1.114 \mathrm{~J} \mathrm{~g}^{-1} \mathrm{~K}^{-1}\right)$ were different. Table 4 presents a summary of estimates of the specific heat parameters for selected organic origin materials. The calculations were made in reference to the research results published by DeLapp and LeBoeuf (2004) [20] for Pahokee peat and the $c_{p}$ values for the temperatures of $0{ }^{\circ} \mathrm{C}$ and $25{ }^{\circ} \mathrm{C}$. These compiled estimates show that high-calorie coal (Anthracite with residual ash equal to $4.7 \%$ ) had the lowest specific heat characteristics. The estimated $c_{p}$ value, regardless of temperature, increased with increasing residual ash content in the coal mass (Gliwice coal with ash content equal to $5.2 \%$ ). The results of this study indicate a similar tendency for the organic soils considered. Besides, the specific heat capacity estimators of DeLapp and LeBoeuf (2004) [20] were close to those obtained for the moss peat (Table 4) with low nitrogen content and high organic carbon content.

Table 4. Specific heat capacity of selected organic materials calculated based on published data as well as study results.

\begin{tabular}{lcccc}
\hline \multirow{2}{*}{ Organic Materials } & \multirow{2}{*}{ Source of Data } & \multicolumn{3}{c}{ Specific Heat Capacity Estimators } \\
\cline { 3 - 5 } & & $\boldsymbol{c}_{\boldsymbol{p}, \mathbf{0}}$ & $\boldsymbol{c}_{\boldsymbol{p}, \mathbf{2 5}}$ & $\boldsymbol{C}_{\mathbf{1}} \mathbf{\boldsymbol { }}^{\mathbf{\$}}$ \\
\hline Anthracite & {$[55]$} & 0.910 & 0.996 & 0.00344 \\
Coal & & 1.010 & 1.113 & 0.00412 \\
\hline Wood & {$[53]$} & 1.114 & 1.229 & 0.00460 \\
Softwood & {$[56]$} & 0.967 & 1.104 & 0.00548 \\
\hline Pahokee peat & {$[20]$} & 1.000 & 1.100 & 0.00400 \\
\hline Overall organic soils & & 1.202 & 1.310 & 0.00432 \\
Moss peat & & 1.040 & 1.129 & 0.00356 \\
Reed peat & & 1.128 & 1.235 & 0.00428 \\
Sedge moss peat & & 1.236 & 1.346 & 0.00440 \\
Sedge reed peat & & 1.244 & 1.353 & 0.00436 \\
Alder peat & & 1.299 & 1.413 & 0.00456 \\
Moorsh & & 1.214 & 1.320 & 0.00424 \\
\hline
\end{tabular}

$c_{p, 0}$ and $c_{p, 25}$ indicate the specific heat capacity in $\mathrm{J} \mathrm{g}^{-1} \mathrm{~K}^{-1}$ for temperatures $0{ }^{\circ} \mathrm{C}$ and $25^{\circ} \mathrm{C}$, respectively; $\$$-slope estimated from the $c_{p}$ value determined for the temperatures of $0{ }^{\circ} \mathrm{C}$ and $25^{\circ} \mathrm{C}$ according to DeLapp and LeBouf (2004) measurements for comparison purposes; * - an example of heat capacity for the so-called Gliwice coal.

Specific heat capacity prediction model of hard coal is described by a complex regression equation considering, among others, carbon and nitrogen content [60]. Both components but also their ratio (C:N), which is an indicator of soil degradation [6], were also major predictors in modeling the $C_{0}$ and $C_{1}$ parameters in the $c_{p}(T)$ relationships in the studied peat soils. Moreover, the $C_{0}$ and $C_{1}$ parameters could also be approximated by only using $\mathrm{N}$ content. However, other parameters also add a significant influence. The importance of ash content in predicting $C_{1}$ value should be emphasized. It is determined by 
measuring the SOM value in the combustion of organic matter and is indirectly a parameter explaining the organic carbon content in soils [61]. The importance of this soil property is also evident in the predictive model of the moisture content in organic soils [62] and the estimation of their soil bulk density [63]. Hence, one of the easiest soil properties to measure can also be used to estimate several more complex characteristics. The polynomial equation that interpolates the $C_{1}$ value can be used to predict the slope of the $c_{p}(T)$ relation in a wide range of peat-muck soil (1.5\% to 30\%). Future research should, however, explain the occurrence of a maximum $C_{1}$ value with an ash content of about $13 \%$ (equation in Figure $6 \mathrm{~d}$ ), which is probably related to the complexity of the organic substance forming the soil system. Prediction of the $C_{0}$ parameter is also complex, as evidenced by the average values of the coefficient of determination oscillating between 0.60 and 0.71 . This study suggests that $C_{0}$ may be treated as an average estimator within an organic soil class (Figure 1). Better characterization of the specific heat capacity of organic soils may require the development of separate estimates for the so-called natural organic matter [64] and for ashes differentiated by the type of organic origin. De Vries (1963) [12] introduced a similar separation of the impact of individual soil components on the estimation of heat capacity of mineral soils using the mixing model.

This study focused also on estimating the $C_{v}$ value for surface soil formations (moorsh). This was because the moisture content changes in these soil layers affects the heat balance of the active surface [65]. Volumetric heat capacity of peat deposits was the subject of research conducted by Dissanayaka et al. (2012) [39] who showed the impact of increase in volumetric solid content on the increase in $C_{v}$ of soil dry matter. The study results confirmed that the use of site-specific parameters describing $c_{p}$ (moorsh formation) in the mixing model (Equation 3) enables the determination of the $C_{v}$ values similar to those measured using a HTP (Figure 7a). However, it should be stressed a wide range of HTP measurement variation (Figure 4) may result from the heterogeneity of soil samples even on a very small scale [66]. Studies on this issue in organic soils confirm the occurrence of soil properties variability at the pedon scale even with using dense sampling schemes [35,67]. It should be noted that the use of the mixing class model requires very detailed knowledge of the soil system properties, which is not needed when using a thermal probe.

\section{Conclusions}

The research carried out in the study showed that the $c_{p}$ values determined using the MDSC method were lower than those that are routinely used in estimating the volumetric heat capacity of organic soils [12]. The differences in $c_{p}$ value between different origin organic soils explain their chemical properties represented by carbon, nitrogen, and ash content similar to other high organic content materials [60]. The obtained class parameters representing $c_{p}$ values of surface soil layers (moorshes) enable the approximation of $C_{v}$ value in the field conditions using the mixing model. However, the applicability of $c_{p}$ value, obtained from the MDSC method, in the mixing model for different peat deposit requires further study in steady-state conditions. It results from the low range of field moisture content changes in the field monitoring in the such type soils [35]. The performed research indicates that combining the mixing model with known $c_{p}$ values and direct $C_{v}$ measurement appears to be a promising tool enabling the prediction of the actual geometry status of the different origin peat and muck soils with a low initial volume. However, this methodology will require an additional validation through detailed studies where simultaneous measurements of the volumetric heat capacity and volume changes are performed. Diversifications of the mixing model characteristics for moorsh and peat soils indicates the need of the inclusion of the proper heat parameters for soil horizons in the models used for developing scenarios for sustainable management of those area. The conducted investigations of the heat capacity $\left(c_{p}\right.$ and $\left.C_{v}\right)$ of the degraded peat soils will be helpful for the better clarification and more detailed examination of the heat movement processes in peat-moorsh soil profiles, as well as to better understanding of the gas exchange at active soil surface. The approach used in this study seems to be a promising tool for 
assessment of heat capacity for European drained peat soils. However, the data set should be extended to samples representing different peat soils from other European locations.

Supplementary Materials: The following supporting information can be downloaded at: https: / / www.mdpi.com/article/10.3390/app12031579/s1, Table S1: Results of cp_T_mesurements.

Author Contributions: The main conception of this article should be attributed to T.G.; field data collection: T.G. and G.K.; laboratory analyses of soil thermo-physical properties: E.O.-L., T.G. and G.K.; statistical data analysis: T.G., C.K. and J.S.; writing of paper: T.G., C.K. and J.S. All authors have read and agreed to the published version of the manuscript.

Funding: This research was founded by the Polish Ministry of Science and Higher Education for statutory activities of the Institute of Environmental Engineering, Warsaw University of Life Sciences-SGGW.

Institutional Review Board Statement: Not applicable.

Informed Consent Statement: Not applicable.

Data Availability Statement: Not applicable.

Conflicts of Interest: The authors declare no conflict of interest.

\section{References}

1. Brandyk, T.; Szatylowicz, J.; Oleszczuk, R.; Gnatowski, T. Water-Related Physical Attributes of Organic Soils. In Organic Soils and Peat Materials for Sustainable Agriculture; CRC Press: Boca Raton, FL, USA, 2002; ISBN 978-0-429-11792-3.

2. Chambers, F.M.; Beilman, D.W.; Yu, Z. Methods for Determining Peat Humification and for Quantifying Peat Bulk Density, Organic Matter and Carbon Content for Palaeostudies of Climate and Peatland Carbon Dynamics. Mires Peat 2011, 7, 1-10.

3. Gnatowski, T.; Szatyłowicz, J.; Brandyk, T. Effect of Peat Decomposition on the Capillary Rise in Peat-Moorsh Soils. Int. Agrophys. 2002, 16, 97-102.

4. Liu, H.; Lennartz, B. Hydraulic Properties of Peat Soils along a Bulk Density Gradient-A Meta Study. Hydrol. Processes 2019, 33, 101-114. [CrossRef]

5. $\mathrm{Mu}, \mathrm{Z}$.; Huang, A.; Ni, J.; Xie, D. Linking Annual N2O Emission in Organic Soils to Mineral Nitrogen Input as Estimated by Heterotrophic Respiration and Soil C/N Ratio. PLoS ONE 2014, 9, e96572. [CrossRef] [PubMed]

6. Krüger, J.P.; Leifeld, J.; Glatzel, S.; Szidat, S.; Alewell, C. Biogeochemical Indicators of Peatland Degradation-A Case Study of a Temperate Bog in Northern Germany. Biogeosciences 2015, 12, 2861-2871. [CrossRef]

7. Leifeld, J. Distribution of Nitrous Oxide Emissions from Managed Organic Soils under Different Land Uses Estimated by the Peat C/N Ratio to Improve National GHG Inventories. Sci. Total Environ. 2018, 631-632, 23-26. [CrossRef] [PubMed]

8. Fang, C.; Moncrieff, J.B. A Model for Soil CO2 Production and Transport 1:: Model Development. Agric. For. Meteorol. 1999, 95, 225-236. [CrossRef]

9. Mäkiranta, P.; Laiho, R.; Fritze, H.; Hytönen, J.; Laine, J.; Minkkinen, K. Indirect Regulation of Heterotrophic Peat Soil Respiration by Water Level via Microbial Community Structure and Temperature Sensitivity. Soil Biol. Biochem. 2009, 41, 695-703. [CrossRef]

10. Kluge, B.; Wessolek, G.; Facklam, M.; Lorenz, M.; Schwärzel, K. Long-term Carbon Loss and CO2-C Release of Drained Peatland Soils in Northeast Germany. Eur. J. Soil Sci. 2008, 59, 1076-1086. [CrossRef]

11. Wang, C.; Amon, B.; Schulz, K.; Mehdi, B. Factors That Influence Nitrous Oxide Emissions from Agricultural Soils as Well as Their Representation in Simulation Models: A Review. Agronomy 2021, 11, 770. [CrossRef]

12. De Vries, D.A. Thermal Properties of Soils. In Physics of Plant Environment; van Wijk, W.R., Ed.; North Holland Publishing: Amsterdam, The Netherlands, 1963; pp. 210-234.

13. Campbell, G.S.; Calissendorff, C.; Williams, J.H. Probe for Measuring Soil Specific Heat Using A Heat-Pulse Method. Soil Sci. Soc. Am. J. 1991, 55, 291-293. [CrossRef]

14. Ochsner, T.E.; Horton, R.; Ren, T. A New Perspective on Soil Thermal Properties. Soil Sci. Soc. Am. J. 2001, 65, 1641-1647. [CrossRef]

15. Lu, Y.; Wang, Y.; Ren, T. Using Late Time Data Improves the Heat-Pulse Method for Estimating Soil Thermal Properties with the Pulsed Infinite Line Source Theory. Vadose Zone J. 2013, 12, 1-9. [CrossRef]

16. Weiss, R.; Shurpali, N.J.; Sallantaus, T.; Laiho, R.; Laine, J.; Alm, J. Simulation of Water Table Level and Peat Temperatures in Boreal Peatlands. Ecol. Model. 2006, 192, 441-456. [CrossRef]

17. Reading, M.; Elliott, D.; Hill, V.L. A New Approach to the Calorimetric Investigation of Physical and Chemical Transitions. J. Therm. Anal. 1993, 40, 949-955. [CrossRef]

18. Gill, P.; Sauerbrunn, S.; Reading, M. Modulated Differential Scanning Calorimetry. J. Therm. Anal. Calorim. 2007, 40, 931-939. [CrossRef]

19. Kozlowski, T. Modulated Differential Scanning Calorimetry (MDSC) Studies on Low-Temperature Freezing of Water Adsorbed on Clays, Apparent Specific Heat of Soil Water and Specific Heat of Dry Soil. Cold Reg. Sci. Technol. 2012, 78, 89-96. [CrossRef] 
20. DeLapp, R.C.; LeBoeuf, E.J. Thermal Analysis of Whole Soils and Sediment. J. Environ. Qual. 2004, 33, 330-337. [CrossRef] [PubMed]

21. Carslaw, H.S.; Jaeger, J.C. Conduction of Heat in Solids; Oxford University Press: Oxford, UK, 1959.

22. Kluitenberg, G.J.; Ham, J.M.; Bristow, K.L. Error Analysis of the Heat Pulse Method for Measuring Soil Volumetric Heat Capacity. Soil Sci. Soc. Am. J. 1993, 57, 1444-1451. [CrossRef]

23. He, H.; Dyck, M.F.; Horton, R.; Ren, T.; Bristow, K.L.; Lv, J.; Si, B. Development and Application of the Heat Pulse Method for Soil Physical Measurements. Rev. Geophys. 2018, 56, 567-620. [CrossRef]

24. Bristow, K.L.; Kluitenberg, G.J.; Goding, C.J.; Fitzgerald, T.S. A Small Multi-Needle Probe for Measuring Soil Thermal Properties, Water Content and Electrical Conductivity. Comput. Electron. Agric. 2001, 31, 265-280. [CrossRef]

25. Ren, T.; Ochsner, T.E.; Horton, R.; Ju, Z. Heat-Pulse Method for Soil Water Content Measurement. Soil Sci. Soc. Am. J. 2003, 67, 1631-1634. [CrossRef]

26. Basinger, J.M.; Kluitenberg, G.J.; Ham, J.M.; Frank, J.M.; Barnes, P.L.; Kirkham, M.B. Laboratory Evaluation of the Dual-Probe Heat-Pulse Method for Measuring Soil Water ContentContribution No. 03-204-J from the Kansas Agric. Exp. Stn., Manhattan, KS. Vadose Zone J. 2003, 2, 389-399. [CrossRef]

27. Liu, X.; Ren, T.; Horton, R. Determination of Soil Bulk Density with Thermo-Time Domain Reflectometry Sensors. Soil Sci. Soc. Am. J. 2008, 72, 1000-1005. [CrossRef]

28. Knight, J.H.; Kluitenberg, G.J.; Kamai, T.; Hopmans, J.W. Semianalytical Solution for Dual-Probe Heat-Pulse Applications That Accounts for Probe Radius and Heat Capacity. Vadose Zone J. 2012, 11, 1-16. [CrossRef]

29. Knight, J.H.; Kluitenberg, G.J.; Kamai, T. The Dual Probe Heat Pulse Method: Interaction between Probes of Finite Radius and Finite Heat Capacity. J. Eng. Math. 2016, 99, 79-102. [CrossRef]

30. Heitman, J.L.; Xiao, X.; Horton, R.; Sauer, T.J. Sensible Heat Measurements Indicating Depth and Magnitude of Subsurface Soil Water Evaporation. Water Resour. Res. 2008, 44, 1-7. [CrossRef]

31. Zhang, M.; Lu, Y.; Ren, T.; Horton, R. In-Situ Probe Spacing Calibration Improves the Heat Pulse Method for Measuring Soil Heat Capacity and Water Content. Soil Sci. Soc. Am. J. 2020, 84, 1620-1629. [CrossRef]

32. Oleszczuk, R.; Szatylowicz, J.; Brandyk, T.; Gnatowski, T. An Analysis of the Influence of Shrinkage on Water Retention Characteristics of Fen Peat-Moorsh Soil. SUO 2000, 51, 139-147.

33. Peng, X.; Horn, R. Anisotropic Shrinkage and Swelling of Some Organic and Inorganic Soils. Eur. J. Soil Sci. 2007, 58, 98-107. [CrossRef]

34. Kechavarzi, C.; Dawson, Q.; Leeds-Harrison, P.B. Physical Properties of Low-Lying Agricultural Peat Soils in England. Geoderma 2010, 154, 196-202. [CrossRef]

35. Szatylowicz, J.; Gnatowski, T.; Szejba, D.; Oleszczuk, R.; Brandyk, T.; Kechavarzi, C. Moisture Content Variability in Drained Fen Soil. In Wetlands Monitoring, Modelling and Management; Okruszko, T., Maltby, E., Szatyłowicz, J., Swiatek, D., Kotowski, W., Eds.; Taylor \& Francis Group: London, UK, 2007; pp. 113-120. ISBN 978-0-415-40820-2.

36. Schaumann, G.E.; Antelmann, O. Thermal Characteristics of Soil Organic Matter Measured by DSC: A Hint on a Glass Transition. J. Plant. Nutr. Soil Sci. 2000, 163, 179-181. [CrossRef]

37. Kettridge, N.; Baird, A. In Situ Measurements of the Thermal Properties of a Northern Peatland: Implications for Peatland Temperature Models. J. Geophys. Res. Earth Surf. 2007, 112, 1-12. [CrossRef]

38. O'Donnell, J.A.; Romanovsky, V.E.; Harden, J.W.; McGuire, A.D. The Effect of Moisture Content on the Thermal Conductivity of Moss and Organic Soil Horizons From Black Spruce Ecosystems in Interior Alaska. Soil Sci. 2009, 174, 646-651. [CrossRef]

39. Dissanayaka, S.H.; Hamamoto, S.; Kawamoto, K.; Komatsu, T.; Moldrup, P. Thermal Properties of Peaty Soils: Effects of Liquid-Phase Impedance Factor and Shrinkage. Vadose Zone J. 2012, 11. [CrossRef]

40. Mustamo, P.; Ronkanen, A.-K.; Berglund, Ö.; Berglund, K.; Kløve, B. Thermal Conductivity of Unfrozen and Partially Frozen Managed Peat Soils. Soil Tillage Res. 2019, 191, 245-255. [CrossRef]

41. IUSS Working Group WRB. World Reference Base for Soil Resources 2014, International Soil Classification System for Naming Soils and Creating Legends for Soil Maps, Update 2015; FAO: Rome, Italy, 2015.

42. Soil Survey Division Staff. Soil Survey Manual; Soil conservation service. U.S. Department of Agriculture Handbook; Government Printing Office: Washington, DC, USA, 1993; Volume 18.

43. Decagon Devices. Decagon Devices KD2 Pro Thermal Properties Analyzer Operator's Manual, Version 10; Decagon Devices: Pullman, WA, USA, 2008. Available online: http:/ / manuals.decagon.com/Manuals/13351_KD2\%20Pro_Web.pdf (accessed on 8 December 2011).

44. ISO. ISO 14235 Soil Quality_Determination of Organic Carbon by Sulfochromic Oxidation; International Standard Organisation: Geneva, Switzerland, 1998.

45. Górska, A.; Szulc, K.; Ostrowska-Ligęza, E.; Wirkowska, M.; Bryś, J. The Influence of Trehalose-Maltodextrin and LactoseMaltodextrin Matrices on Thermal and Sorption Properties of Spray-Dried $\beta$-Lactoglobulin-Vitamin D3 Complexes. J. Anal. Calorim 2013, 112, 429-436. [CrossRef]

46. De Vries, D.A. A Nonstationary Method for Determining Thermal Conductivity of Soil in Situ. Soil Sci. 1952, 73, 83-90. [CrossRef]

47. Mengistu, A.G.; van Rensburg, L.D.; Mavimbela, S.S.W. The Effect of Soil Water and Temperature on Thermal Properties of Two Soils Developed from Aeolian Sands in South Africa. CATENA 2017, 158, 184-193. [CrossRef]

48. R Core Team. R: A Language and Environment for Statistical Computing; R Foundation for Statistical Computing: Vienna, Austria, 2021. 
49. Gnatowski, T.; Szatyłowicz, J.; Pawluśkiewicz, B.; Oleszczuk, R.; Janicka, M.; Papierowska, E.; Szejba, D. Field Calibration of TDR to Assess the Soil Moisture of Drained Peatland Surface Layers. Water 2018, 10, 1842. [CrossRef]

50. Cabezas, A.; Gelbrecht, J.; Zwirnmann, E.; Barth, M.; Zak, D. Effects of Degree of Peat Decomposition, Loading Rate and Temperature on Dissolved Nitrogen Turnover in Rewetted Fens. Soil Biol. Biochem. 2012, 48, 182-191. [CrossRef]

51. Batjes, N.H. Total Carbon and Nitrogen in the Soils of the World. Eur. J. Soil Sci. 2014, 65, 10-21. [CrossRef]

52. McKenzie, J.M.; Siegel, D.I.; Rosenberry, D.O.; Glaser, P.H.; Voss, C.I. Heat Transport in the Red Lake Bog, Glacial Lake Agassiz Peatlands. Hydrol. Processes 2007, 21, 369-378. [CrossRef]

53. Kollmann, F.F.P.; Cote, W.A. Principles of Wood Science and Technology; Springer: Berlin/Heidelberg, Germany; New York, NY, USA, 1968; pp. 240-256.

54. Fasina, O.O.; Sokhansanj, S. Bulk Thermal Properties of Alfalfa Pellets. Can. Agric. Eng. 1995, $37,91$.

55. Tomeczek, J.; Palugniok, H. Specific Heat Capacity and Enthalpy of Coal Pyrolysis at Elevated Temperatures. Fuel 1996, 75, 1089-1093. [CrossRef]

56. Gupta, M.; Yang, J.; Roy, C. Specific Heat and Thermal Conductivity of Softwood Bark and Softwood Char Particles. Fuel 2003, 82, 919-927. [CrossRef]

57. Adl-Zarrabi, B.; Boström, L.; Wickström, U. Using the TPS Method for Determining the Thermal Properties of Concrete and Wood at Elevated Temperature. Fire Mater. Int. J. 2006, 30, 359-369. [CrossRef]

58. Pauner, M.A.; Bygbjerg, H. Spontaneous Ignition in Storage and Production Lines: Investigation on Wood Pellets and Protein Powders. Fire Mater. 2007, 31, 477-494. [CrossRef]

59. Guo, W.; Lim, C.J.; Bi, X.; Sokhansanj, S.; Melin, S. Determination of Effective Thermal Conductivity and Specific Heat Capacity of Wood Pellets. Fuel 2013, 103, 347-355. [CrossRef]

60. Speight, J.G. Handbook of Coal Analysis; John Wiley \& Sons: Hoboken, NJ, USA, 2015; ISBN 978-1-119-03791-0.

61. Bol, R.A.; Harkness, D.D.; Huang, Y.; Howard, D.M. The Influence of Soil Processes on Carbon Isotope Distribution and Turnover in the British Uplands. Eur. J. Soil Sci. 1999, 50, 41-51. [CrossRef]

62. Oleszczuk, R.; Gnatowski, T.; Brandyk, T.; Szatylowicz, J. Calibration of TDR for Moisture Content Monitoring in Moorsh Layers. In Wetlands Monitoring, Modelling and Management; Okruszko, T., Maltby, E., Szatylowicz, J., Swiatek, D., Kotowski, W., Eds.; Taylor \& Francis Group: London, UK, 2007; pp. 121-124. ISBN 978-0-415-40820-2.

63. Deverel, S.J.; Ingrum, T.; Leighton, D. Present-Day Oxidative Subsidence of Organic Soils and Mitigation in the Sacramento-San Joaquin Delta, California, USA. Hydrogeol J. 2016, 24, 569-586. [CrossRef] [PubMed]

64. DeLapp, R.C.; LeBoeuf, E.J.; Chen, J.; Gu, B. Advanced Thermal Characterization of Fractionated Natural Organic Matter. J. Environ. Qual. 2005, 34, 842-853. [CrossRef] [PubMed]

65. Katul, G.G.; Oren, R.; Manzoni, S.; Higgins, C.; Parlange, M.B. Evapotranspiration: A Process Driving Mass Transport and Energy Exchange in the Soil-Plant-Atmosphere-Climate System. Rev. Geophys. 2012, 50, 1-25. [CrossRef]

66. Philip, J.R.; Kluitenberg, G.J. Errors of Dual Thermal Probes Due to Soil Heterogeneity across a Plane Interface. Soil Sci. Soc. Am. J. 1999, 63, 1579-1585. [CrossRef]

67. Hewelke, E.; Szatyłowicz, J.; Gnatowski, T.; Oleszczuk, R. Zmienność przestrzenna uwilgotnienia hydrofobowej gleby organicznej w warunkach przepływu preferencyjnego. Rocz. Ochr. Środowiska 2014, 16, 580-607. 